\title{
HAMBATAN KOMUNIKASI TERAPEUTIK BIDAN KEPADA IBU HAMIL DALAM UPAYA PENURUNAN ANGKA KEMATIAN IBU (AKI) DI SERANG
}

\author{
Studi Deskriptif Kualitatif tentang Hambatan Komunikasi Terapeutik Bidan kepada Ibu \\ Hamil di Puskesmas Tunjung Teja, Kabupaten Serang
}

\author{
Ditha Prasanti \\ Ikhsan Fuady \\ Prodi Ilmu Komunikasi Universitas Padjadjaran \\ dithaprasanti@gmail.com
}

\begin{abstract}
As a health worker, midwife should have a good therapeutic communication skills, so that he can establish a relationship of trust with the patient, providing professional satisfaction in obstetric care, and improve the image of the profession of midwifery. But the most important is to apply their knowledge to help their fellow human beings.
\end{abstract}

Maternal Mortality Rate (MMR) is one of the indicators that should be considered by the midwife. If the Maternal Mortality Rate (MMR) increases, the solution must be found in order to prevent this AKI. This is why researchers are interested to raise the research on Therapeutic Communication Barriers To Midwives Pregnancy Prevention in Maternal Mortality Rate (MMR). The purpose of this study is the researcher wanted to know how therapeutic communication barriers between midwives to pregnant women in the prevention of maternal mortality is increasing. Based on data obtained from the Department of Health, the maternal mortality is very high in Serang district. Therefore, in this study, the researchers raised the case of therapeutic communication barriers midwives to pregnant women in the district of Serang.

In this study, researcher used a qualitative approach with descriptive methods. The data collection techniques are observation, interviews, and documentation study. The theory of communication shall be used to analyze this research is the theory of symbolic interaction.

Results of research have shown that therapeutic communication barriers that occur between midwives to pregnant women in Puskesmas Tunjung Teja Serang Regency is a semantic barriers (language), cultural barriers, and psychological barriers.

Keywords:

Barriers, Therapeutic Communication, Midwives, Pregnancy, Serang

\begin{abstract}
ABSTRAK
Sebagai seorang tenaga kesehatan, Bidan harus memiliki keterampilan komunikasi terapeutik yang baik, agar dia dapat menjalin hubungan rasa percaya dengan pasien, memberikan kepuasan profesional dalam pelayanan kebidanan, dan meningkatkan citra profesi kebidanan. Namun yang terpenting adalah mengamalkan ilmunya untuk menolong terhadap sesama manusia.
\end{abstract}


Angka Kematian Ibu (AKI) adalah salah satu indikator yang harus diperhatikan oleh para Bidan. Jika Angka Kematian Ibu (AKI) semakin meningkat, maka harus segera ditemukan solusi dalam upaya pencegahan AKI ini. Hal inilah yang menyebabkan peneliti tertarik untuk mengangkat penelitian tentang Hambatan Komunikasi Terapeutik Bidan Kepada Ibu Hamil dalam Upaya Pencegahan Angka Kematian Ibu (AKI). Tujuan penelitian ini adalah peneliti ingin mengetahui bagaimana hambatan komunikasi terapeutik antara Bidan kepada Ibu Hamil dalam upaya pencegahan AKI yang semakin meningkat. Berdasarkan data yang diperoleh dari Dinas Kesehatan bahwa AKI di kabupaten Serang sangat tinggi. Oleh karena itu, dalam penelitian ini, peneliti mengangkat kasus hambatan komunikasi terapeutik Bidan kepada Ibu Hamil di kabupaten Serang.

Dalam penelitian ini, peneliti menggunakan pendekatan kualitatif dengan metode deskriptif. Adapun teknik pengumpulan data yang digunakan adalah observasi, wawancara, dan studi dokumentasi. Teori komunikasi yang sesuai digunakan untuk menganalisis penelitian ini adalah teori interaksi simbolik.

Hasil penelitian yang telah dilakukan menunjukkan bahwa hambatan komunikasi terapeutik yang terjadi antara Bidan kepada Ibu Hamil di Puskesmas Tunjung Teja Kabupaten Serang adalah hambatan semantik (bahasa), hambatan budaya, dan hambatan psikologis.

Kata Kunci: Hambatan, Komunikasi Terapeutik, Bidan, Ibu Hamil, Serang

\section{PENDAHULUAN}

Komunikasi terapeutik sangat dekat dengan kehidupan manusia, karena hampir setiap individu telah mengalaminya. Jika seseorang sakit, bertemu dengan tenaga medis, terjadilah komunikas terapeutik. Begitupun halnya tenaga medis yang terdiri dari dokter, perawat, dan bidan. Bidan harus memiliki keterampilan komunikasi terapeutik yang baik, agar dia dapat menjalin hubungan rasa percaya dengan pasien, memberikan kepuasan profesional dalam pelayanan kebidanan, dan meningkatkan citra profesi kebidanan. Namun yang terpenting adalah mengamalkan ilmunya untuk menolong terhadap sesama manusia.

Komunikasi menciptakan hubungan antara bidan dengan pasien untuk mengenal kebutuhan dan menentukan rencana tindakan. Kemampuan komunikasi tidak terlepas dari tingkah laku yang melibatkan aktifitas fisik, mental dan dipengaruhi oleh latar belakang sosial, pengalaman, usia, pendidikan dan tujuan. Komunikasi terapeutik adalah komunikasi yang direncanakan secara sadar, bertujuan dan dipusatkan untuk kesembuhan pasien. Komunikasi terapeutik mengarah pada bentuk komunikasi interpersonal. Stuart G.W. (1998) mengatakan bahwa komunikasi terapeutik merupakan hubungan interpesonal antara bidan dengan pasien, dalam hubungan ini bidan dan pasien memperoleh pengalaman belajar bersama dalam rangka memperbaiki pengalaman emosional pasien.

Seorang bidan tentu harus
memerhatikan proses komunikasi
terapeutik yang dilakukannya selama
berinteraksi dengan pasien. Pasien akan
mengharapkan pelayanan yang optimal
dari tenaga medis agar tercapainya
perolehan informasi yang dibutuhkan


tentang kesehatannya. Jika bidan mampu memberikan pelayanan yang terbaik kepada pasiennya, maka hal inipun akan meningkatkan citra profesi kebidanan. Bidan dikenal oleh masyarakat sebagai tenaga medis yang biasa membantu proses persalinan ibu hamil. Dalam hal ini, bidan pun perlu memahami pentingnya Angka Kematian Ibu (AKI) menurun atau meningkat di suatu daerah.

$$
\text { Angka Kematian Ibu (AKI) }
$$

merupakan hal yang sangat penting diperhatikan oleh Bidan sebagai salah satu tenaga medis yang menangani langsung komunikasi terapeutik kepada ibu hamil. Berdasarkan data yang diperoleh dari Dinas Kesehatan Kabupaten Serang yang terdapat di situs republika online, yaitu Kepala Bidang Pelayanan Kesehatan Dinkes Kabupaten Serang, Agus Sukmayadi, menurutnya medis sangat berperan untuk menekan angka kematian ibu, melalui sistem rujukan yang dimaksimalkan dengan pelayanan prima untuk menyelamatkan ibu dan bayi. Namun, selain medis yang menjadi faktor tingginya kematian ibu juga faktor sosial masyarakat yang belum sadar akan pentingnya keselamatan. Meski sebelumnya juga faktor ekonomi yang sering menjadi alasan utama penyebab kematian tersebut. Hal inipun dipertegas oleh penuturan Sekretaris Daereah Kabupaten Serang, Lalu Atharussalam, yang menegaskan bahwa tingginya angka kematian ibu (AKI) di Serang harus menjadi bahan evaluasi dari kinerja dinkes dan mitranya dalam menekan aki tersebut, karena AKI di Kabupaten Serang tertinggi di Banten. Untuk menurunkan AKI, Dinas Kesehatan harus bekerja sama dengan organisasi-organisasi lainnya. Dalam hal ini, pihak Dinas Kesehatan telah membuat MAF (MDGs Acseleration framework) atau kerangka kerja untuk mengoptimalkan MDGs. Komunikasi terapeutik yang dilakukan Bidan kepada Ibu Hamil pun tentu harus semakin optimal, sebagai upaya untuk menurunkan Angka Kematian Ibu (AKI) di Kabupaten Serang.

Berdasarkan latar belakang di atas, peneliti semakin tertarik untuk melakukan penelitian tentang Hambatan Komunikasi Terapeutik Bidan Kepada Ibu Hamil Dalam Upaya Penurunan Angka Kematian Ibu (AKI) di Kabupaten Serang. Peneliti ingin mengetahui bagaimana hambatan komunikasi terapeutik yang terjadi antara Bidan dengan Ibu Hamil tersebut. Hambatan apa yang menyebabkan AKI ini tetap tinggi padahal komunikasi terapeutik dari Bidan kepada Ibu Hamil terus berlangsung. Apalagi mengingat bahwa data yang menunjukkan AKI yang tinggi terdapat di Kabupaten Serang. Dinas Kesehatan pun terus mengupayakan bekerjasama dengan semua pihak, termasuk rumah sakit dan Puskesmas yang tersebar di Kabupaten Serang.

Dalam penelitian ini, peneliti mengambil lokasi penelitian di Puskesmas Tunjung Teja, Kabupaten Serang. Hal ini dikarenakan data dari Dinas Kesehatan yang menunjukkan AKI di puskesmas tersebut sangat tinggi.

Peneliti menggunakan pendekatan kualitatif dengan metode deskriptif. Adapun teknik pengumpulan data yang digunakan adalah observasi, wawancara, dan studi dokumentasi. Peneliti juga menggunakan teori komunikasi yang cocok digunakan untuk menganalisis penelitian ini yakni teori interaksi simbolik.

\section{KERANGKA KONSEPTUAL Komunikasi Terapeutik}


Komunikasi terapeutik adalah komunikasi yang direncanakan secara sadar dan tujuan dipusatkan untuk kesembuhan pasien. Komunikasi terapeutik dianggap sebagai proses yang khusus dan memiliki arti dalam hubungan antar manusia. Pada praktik kebidanan, komunikasi terapeutik lebih bermakna karena merupakan modal utama dalam mengimplementasikan asuhan kebidanan. Artinya, dalam komunikasi terapeutik bidan tidak hanya dituntut memiliki pengalaman ilmu, intelektual, dan teknik menolong pasien, tetapi juga didukung kasih sayang, peduli dan berkomunikasi dengan baik (Machfoedz: 2009). Bidan yang memiliki keterampilan komunikasi terapeutik yang baik, memungkinkan dia mudah menjalin hubungan rasa percaya dengan klien, memberikan kepuasan profesional dalam pelayanan kebidanan, dan meningkatkan citra profesi kebidanan. Namun yang terpenting adalah mengamalkan ilmunya untuk menolong terhadap sesama manusia.

Komunikasi terapeutik ini bertujuan untuk mengurangi beban perasaan dan rasa takut yang ada pada pasien, mengurangi keraguan pasien serta dapat mempengaruhi orang lain, lingkungan dan dirinya sendiri (Mahfud 2009). Pentingnya komunikasi terapeutik dalam membantu menurunkan rasa sakit dan takut dalam proses persalinan sangat diperlukan. Oleh karena itu, bidan dalam persalinan harus bisa membuat pasien lebih percaya diri karena bila pasien itu grogi atau gugup dalam persalinanannya baik secara fisik maupun mental belum siap maka timbul rasa ketakutan sehingga rasa sakit dan takut itu akan bertambah, maka dengan komunikasi terapeutik inilah dapat mengatasi masalah pasien tersebut.
Komunikasi terapeutik adalah komunikasi yang direncanakan secara sadar, bertujuan dan dipusatkan untuk kesembuhan pasien. Komunikasi terapeutik termasuk komunikasi interpersonal dengan titik tolak saling memberikan pengertian antar bidan dengan pasien. Persoalan mendasar dan komunikasi ini adalah adanya saling membutuhan antara bidan dan pasien, sehingga dapat dikategorikan ke dalam komunikasi pribadi di antara bidan dan pasien, bidan membantu dan pasien menerima bantuan (Damaiyanti, 2010).

Komunikasi terapeutik bukan pekerjaan yang bisa dikesampingkan, namun harus direncanakan, disengaja, dan merupakan tindakan profesional. Akan tetapi, jangan sampai karena terlalu asyik bekerja, kemudian melupakan pasien sebagai manusia dengan beragam latar belakang dan masalahnya. (Machfoed, 2009). Menurut Stuart dan Sundeen (dalam Machfoed, 2009), tujuan hubungan terapeutik diarahkan pada pertumbuhan klien meliputi :

1. Membantu klien untuk memperjelas dan mengurangi beban perasaan dan pikiran serta dapat mengambil tindakan untuk mengubah situasi yang ada bila klien pecaya pada hal yang diperlukan.

2. Mengurangi keraguan, membantu dalam hal mengambil tindakan yang efektif dan mempertahankan kekuatan egonya.

3. Mempengaruhi orang lain, lingkungan fisik dan dirinya sendiri.

Tujuan terapeutik akan tercapai bila bidan memiliki karakteristik sebagai berikut (Machfoed,2009) :
a. Kesadaran diri.
b. Klarifikasi nilai.
c. Eksplorasi perasaan.
d. Kemampuan untuk menjadi model peran
e. Rasa tanggung jawab dan etik. 
Menurut Roger dalam (Machfoed: 2009), terdapat beberapa karakteristik dari seorang bidan yang dapat memfasilitasi tumbuhnya hubungan yang terapeutik. Berikut komponen-komponen komunikasi terapeutik tersebut antara lain:

a. Kejujuran (trustworthy) : Kejujuran merupakan modal utama agar dapat melakukan komunikasi yang bernilai terapeutik, tanpa kejujuran mustahil dapat membina hubungan saling percaya. Klien hanya akan terbuka dan jujur pula dalam memberikan informasi yang benar hanya bila yakin bahwa bidan dapat dipercaya.

b. Tidak membingungkan dan cukup ekspresif: Dalam berkomunikasi hendaknya bidan menggunakan katakata yang mudah dimengerti oleh klien. Komunikasi nonverbal harus mendukung komunikasi verbal yang disampaikan. Ketidaksesuaian dapat menyebabkan klien menjadi bingung.

c. Bersikap positif; Bersikap positif dapat ditunjukkan dengan sikap yang hangat, penuh perhatian dan penghargaan terhadap klien. Roger menyatakan inti dari hubungan terapeutik adalah kehangatan, ketulusan, pemahaman yang empati dan sikap positif.

d. Empati bukan simpati; Sikap empati sangat diperlukan dalam asuhan kebidanan, karena dengan sikap ini perawat akan mampu merasakan dan memikirkan permasalahan klien seperti yang dirasakan dan dipikirkan oleh klien. Dengan empati seorang bidan dapat memberikan alternatif pemecahan masalah bagi klien, karena meskipun dia turut merasakan permasalahan yang dirasakan kliennya, tetapi tidak larut dalam masalah tersebut sehingga perawat dapat memikirkan masalah yang dihadapi klien secara objektif. e. Mampu melihat permasalahan klien dari kacamata klien; Dalam memberikan asuhan keperawatan perawat harus berorientasi pada klien Taylor, dkk, 1997 (dalam Machfoed: 2009) . Untuk itu agar dapat membantu memecahkan masalah klien perawat harus memandang permasalahan tersebut dari sudut pandang klien. Untuk itu perawat harus menggunakan teknik active listening dan kesabaran dalam mendengarkan ungkapan klien. Jika perawat menyimpulkan secara tergesagesa dengan tidak menyimak secara keseluruhan ungkapan klien akibatnya dapat fatal, karena dapat saja diagnosa yang dirumuskan perawat tidak sesuai dengan masalah klien dan akibatnya tindakan yang diberikan dapat tidak membantu bahkan merusak klien.

f. Menerima klien apa adanya; Jika seseorang diterima dengan tulus, seseorang akan merasa nyaman dan aman dalam menjalin hubungan intim terapeutik.

g. Sensitif terhadap perasaan klien: Tanpa kemampuan ini hubungan yang terapeutik sulit terjalin dengan baik, karena jika tidak sensitif bidan dapat saja melakukan pelanggaran batas, privasi dan menyinggung perasaan klien.

h. Tidak mudah terpengaruh oleh masa lalu klien ataupun diri perawat sendiri. Seseorang yang selalu menyesali tentang apa yang telah terjadi pada masa lalunya tidak akan mampu berbuat yang terbaik hari ini. Sangat sulit bagi perawat untuk membantu klien, jika ia sendiri memiliki segudang masalah dan ketidakpuasan dalam hidupnya. (Machfoed, 2009)

\section{Proses Komunikasi}


Proses komunikasi pada hakikatnya adalah proses penyampaian lambang yang berarti oleh seseorang kepada orang lain, baik dengan maksud agar mengerti maupun agar berubah perilakunya.

Suatu komunikasi dapat dikatakan efektif atau berhasil bilamana di antara penyebar pesan (komunikator) dan penerima pesan (komunikan) terdapat satu pengertian yang sama mengenai isi pesan. Isi pesan disampaikan oleh penyebar melalui lambang yang berarti. Lambanglambang itu dapat dikatakan sebagai "titian" atau "kendaraan" untuk membawa pesan kepada si penerima pesan.

Terlihat bahwa dalam komunikasi terdapat tiga unsur penting, yaitu : komunikator, pesan, dan komunikan. Komunikator adalah sumber yang memiliki ide atau gagasan mengenai sesuatu yang akan disampaikan kepada komunikan. Pesan adalah gagasan yang berupa lambang-lambang yang berarti dan disampaikan oleh komunikator kepada komunikan, sedangkan komunikan adalah orang atau badan yang menerima pesan. Kegiatan komunikasi tidak akan berjalan secara efektif apabila tidak didukung dengan ketiga faktor tersebut yaitu komunikator, pesan, dan komunikan.

Dengan demikian, agar komunikasi berlangsung secara efektif maka kita harus memerhatikan faktor-faktor tersebut, yaitu komunikator, pesan, dan komunikan. Faktor lain yang penting dalam suatu proses komunikasi adalah umpan balik atau efek. Umpan balik memegang peranan penting dalam komunikasi sebab ia menentukan berlanjutnya komunikasi atau berhentinya komunikasi yang dilancarkan oleh komunikator. Dengan kata lain, umpan balik menentukan sukses atau tidaknya sebuah proses komunikasi dilangsungkan.
1. Komunikator

Kredibilitas merupakan salah satu faktor dari komunikator yang mempunyai peranan penting agar pesan yang dikomunikasikan dapat berjalan lancar dan dapat diterima atau dipahami komunikan. Menurut Jalaludin Rakhmat (2008:257), dalam bukunya psikologi komunikasi, kredibilitas adalah, "seperangkat lambang bermakna yang disampaikan oleh komunikator.

2. Pesan

Pesan merupakan seperangkat lambang bermakna yang disampaikan oleh komunikator (Effendy, 1998). Dalam menyampaikan pesan secara lisan, faktor pemilihan kata-kata merupakan hal yang sangat penting agar sasaran yang dituju mengerti dengan maksud yang disampaikan.

a. Pesan harus dirancang dan disampaikan sedemikian rupa sehingga dapat menarik perhatian komunikan.

b. Pesan harus membangkitkan kebutuhan pribadi komunikan dan menyarankan beberapa cara untuk memeroleh kebutuhan tersebut.

c. Pesan harus menyarankan suatu jalan untuk memeroleh kebutuhan tadi yang layak bagi situasi kelompok di mana komunikan berada pada saat ia digerakkan untuk memberikan pendapat dalam mencapai tujuan (Rakhmat, 2008:92).

3. Komunikan

Dari pesan-pesan tersebut, maka seorang komunikator harus dapat menyampaikan pesan dengan baik, 
misalnya bagaimana kejelasan isi pesan tersebut, bahasa yang digunakan apakah mudah dipahami, isi pesan tersebut apakah sesuai dengan kebutuhan masyarakat.

Komunikan memainkan peranan yang sangat penting dalam proses komunikasi, sebab ia menerangkan bagaimana pesan kita diterima dan ditanggapi oleh komunikan atau tidak. Umpan balik dari komunikan bisa bersifat verbal dalam bentuk, seperti "ya" untuk tanda setuju atau "tidak" untuk tanda menolak, bisa juga bersifat non verbal dalam bentuk gerakan anggota kepala tanda tidak mau, mengerutkan kening tanda tidak mengerti, mencibirkan bibir tanda mengejek, dan lain-lain. (Effendy, 1998).

Berkaitan dengan penelitian ini, peneliti akan meneliti hambatan komunikasi yang terjadi dalam komunikasi terapeutik yang dilakukan bidan kepada ibu hamil. Dengan demikian, jelaslah bahwa komunikasi mempunyai peranan penting dalam kehidupan manusia seharihari baik perorangan maupun kelompok.

Seperti yang telah diuraikan sebelumnya dalam latar belakang masalah bahwa penelitian ini juga mengkaji bagaimana bidan sebagai salah satu tenaga medis, berkomunikasi dengan ibu hamil, termasuk dalam kajian komunikasi antar pribadi. Dengan kata lain konsep diri perilaku manusia, tergantung bagaimana pola interaksi individu dengan lingkungannya, bagaimana kita memandang diri kita sendiri dan bagaimana orang lain memandang kita, sangat berpengaruh pada interaksi kita dengan orang lain.

\section{Hambatan Komunikasi}

$\begin{array}{llr}\text { Meskipun } & \text { informasi } & \text { yang } \\ \text { disampaikan } & \text { sebenarnya } & \text { mudah }\end{array}$ dimengerti, tetapi ternyata komunikasi yang terjalin tersebut tidak sesuai dengan apa yang diharapkan atau diinginkan. Hal ini dapat terjadi sebab didalam peleksanaan komunikasi banyak sekali hambatan-hambatan yang mungkin timbul. Penurunan isi dan mutu pesan dapat terjadi pada setiap tahap dalam proses komunikasi mulai dari perumusan konsep gagasan didalam kata-kata sampai saat pemanfaatan yang diterima. Lebih lanjut hambatan-hambatan ini secara umum dapat di klasifikasikan menjadi tiga menurut Arni Muhammad (2009) yaitu :

1. Hambatan Pribadi (Psikologis) adalah gangguan komunikasi yang timbul dari emisi, nilai dan kebiasaan menyimak yang tidak baik. Hambatan pribadi seringkali mencakup jarak psikologi diantaranya orang-orang yang serupa dengan jarak fisik sesungguhnya.

2. Hambatan Fisik adalah gangguan komunikasi yang terjadi di lingkungan tempat berlangsungnya komunikasi.

3. Hambatan Semantik adalah hambatan ini berasal dari keterbatasan simbol-simbol itu sendiri. Ada beberapa karakteristik dari bahasa yang menyebabkan proses decording dalam bahasa semakin sulit antara lain :
a.Bahasa itu statis sedangkan realitasnya dinamis,
b.Bahasa itu terbatas sedangkan realitasnya tidak terbatas,


c.Bahasa itu bersifat abstrak.

Selain tahap-tahap dan akibat adanya hambatan dalam komunikasi, maka umpan balik sangat diperlukan. Umpan balik merupakan arah yang utama bagi pengirim pesan untuk memonitor apakah pesannya dimengerti dan dimanfaatkan oleh penerima sesuai dengan harapannya.

Berdasarkan uraian diatas dapat disimpulkan bahwa komunikasi sangat penting dalam kehidupan sehari-hari. Tanpa komunikasi atau kurangnya komunikasi akan membuat pekerjaan menjadi kurang maksimal dan akan terjadinya kesalahpahaman dalam menangkap suatu informasi.

Komunikasi pun sering dikutip sebagai masalah nomor satu di dalam sebuah hubungan. Jika dua perangkat komunikasi (komunikator dan komunikan) memahami hal ini, serta berusaha untuk sering berkomunikasi, maka tidak akan mengalami permasalahan yang cukup signifikan. Namun sebaliknya jika tidak memperhatikan beberapa faktor penyebab masalah dalam berkomunikasi maka kemungkinan besar lambat laun komunikasi yang dibina akan "mati". Ada beberapa hambatan komunikasi dari perspektif lain yang mungkin terjadi dalam menjalin komunikasi dua arah.

1. Bahasa

Jika seorang komunikator atau komunikan berkomunikasi dengan bahasa yang berbeda, kemungkinan akan terjadi banyak kesalahpahaman bahkan terjadinya hubungan yang tidak jelas. Jika pada proses komunikasi komunikator merasa bahasa yang digunakannya tidak dipahami, maka komunikator harus sering meluangkan waktu untuk menjelaskan tentang beberapa hal yang ingin di bicarakan kepada komunikan.

2. Budaya
Hambatan budaya ini menjadi hal yang sangat penting. Satu pantangan bagi sang komunikator untuk beranggapan, bahwa komunikan tumbuh dengan filosofi, gaya hidup, adat istiadat yang sama. Maka kita tidak boleh "menyamaratakan" penggunaan teknik berkomunikasi kepada setiap komunikan. Hindari anggapan bahwa komunikan mempunyai pemikiran yang sama ketika menghadapi suatu permasalahan. Jika komunikator menemukan miskomunikasi dalam suatu hubungan, atau bahkan komunikan merasa tersinggung, maka cepatlah lakukan analisis mengapa komunikan punya anggapan lain terhadap pesan yang disampaikan. Hal ini bisa saja terjadi karena budaya yang berbeda yang dimiliki oleh sang komunikan. jika hal ini terjadi maka Hormati persepsi komunikan dan cobalah temukan beberapa persamaan persepsi maka disanalah peluang komunikator untuk kembali membangun komunikasi yang "nyambung".

3. Salah paham

Hambatan komunikasi yang paling utama pada awalnya bersumber dari dari satu hal, yaitu kesalahpahaman. Interpretasi, respon, asumsi seseorang dalam menghadapi suatu permasalahan berbeda-beda, komunikan akan memahami yang komunikator katakan. Jika komunikator menelisik lebih jauh jika ada pertentangan dalam suatu proses komunikasi. Dalam hambatan ini komunikator harus menjauhi sikap menyimpan permasalahan atau kesalahpahaman yang terjadi.

4. Sisi historis atau pengalaman

Pada umumnya komunikator menjadikan filosofis dan pengalaman hidup masa lalu sebagai rujukan komunikasi agar sang komunikan mengerti. Tidak ada salahnya melakukan 
hal ini, terkecuali jika komunikator menjadikan pengalaman sebagai rujukan tersebut tidak dengan sikap prasangka, maksudnya memproyeksikan pengalaman hidup terdahulu untuk menjadikan solusi untuk permasalahan komunikan, karena pengalaman hidup yang dialami komunikator terdahulu tidak akan sama persis dengan yang dialami komunikan.

5. Mendominasi pembicaraan

Mendominasi pembicaraan, hal ini sering terjadi.Seorang komunikator merasa pendapatnya paling benar sehingga tidak memberikan kesempatan komunikan untuk berbicara. Bahkan lebih jauh komunikator selalu memotong pembicaraan, padahal pesan yang disampaikan komunikan belum disampaikan secara utuh, sehingga sering terjadi kesalahpahaman. Ketika Berkomunikasi dengan seseorang hindarilah sikap mendominasi pembicaraan agar bisa saling memberikan komentar. Namun jika komunikator melihat hal ini terjadi, cobalah meminta komunikator untuk bersi keras memberikan komentar, agar komunikasi yang dijalin dapat berimbang. (Damaiyanti, 2010)

\section{Teori Interaksi Simbolik}

Esensi dari interaksi simbolik menekankan pada suatu aktivitas yang merupakan ciri khas manusia, yakni komunikasi atau pertukaran simbol yang diberi makna (Mulyana, 2010: 68). Banyak ahli di belakang perspektif ini yang mengatakan bahwa individu sebagai manusia merupakan hal yang paling penting. Mereka mengatakan bahwa individu adalah objek yang bisa secara langsung ditelaah dan dianalisis melalui interaksinya dengan individu yang lain.

Menurut Ralph Larossa dan Donald C. Reitzes (1993) interaksi simbolik pada intinya menjelaskan tentang kerangka referensi untuk memahami bagaimana manusia, bersama dengan orang lain, menciptakan dunia simbolik dan bagaimana cara dunia membentuk perilaku manusia. Interaksi simbolik ada karena ide-ide dasar dalam membentuk makna yang berasal dari pikiran manusia (Mind) mengenai diri (Self), dan hubungannya di tengah interaksi sosial, dan tujuan akhir untuk memediasi, serta menginterpretasi makna di tengah masyarakat (Society) dimana individu tersebut menetap. Mind, Self and Society merupakan judul buku yang menjadi rujukan utama teori interaksi simbolik, merefleksikan tiga konsep utama dari teori. Definisi singkat dari ke tiga ide dasar dari interaksi simbolik, yaitu:

1. Pikiran (Mind)

Pikiran adalah kemampuan untuk menggunakan simbol yang mempunyai makna sosial yang sama, dimana tiap individu harus mengembangkan pikiran mereka melalui interaksi dengan individu lain (West dan Turner, 2007: 102). Simbol yang bermakna adalah tindakan verbal berupa bahasa yang merupakan mekanisme utama interaksi manusia. Penggunaan bahasa atau isyarat simbolik oleh manusia dalam interaksi sosial mereka pada gilirannya memunculkan pikiran (mind) yang memungkinkannya menginternalisasi masyarakat. Jadi menurut Mead, pikiran mensyaratkan adanya masyarakat; dengan kata lain masyarakat harus lebih dulu ada sebelum adanya pikiran (Mulyana, 2010: 84). Dengan demikian pikiran adalah bagian integral dari dari proses sosial, bukan sebaliknya proses sosial adalah produk pikiran. Menurut 
Mead, lewat berfikir yang terutama ditandai degan kesadaran,manusia mampu mencegah tindakannya sendiri untuk sementara, menunda reaksinya terhadap suatu stimulus (Mulyana, 2010: 86). Manusia juga mampu mengambil suatu stimulus diantara sekian banyak stimulus alih-alih bereaksi terhadap stimulus yang pertama dan yang paling kuat. Manusia pun mampu pula memilih suatu tindakan di antara berbagai tindakan yang direncanakan atau dibayangkan.

2. Diri (Self)

Diri adalah kemampuan untuk merefleksikan diri sendiri dari sudut pandang atau pendapat orang lain. Disini diri tidak dapat dilihat dari dalam diri seseorang melalui introspeksi diri. Bagi Mead, diri hanya bisa berkembang melalui kemampuan pengambilan peran, yaitu membayangkan diri dari pandangan orang lain (West dan Turner, 2007 : 103). Konsep melihat diri dari pandangan orang lain sebenarnya sebuah konsep yang pernah disampaikan oleh Charles Cooley pada 1912. Konsepnya adalah the looking glass self yaitu kemampuan melihat diri melalui pantulan dari pandangan orang lain. Cooley meyakini bahwa ada tida prinsip perkembangan sehubungan dengan the looking glass self, yaitu (1) membayangkan penampilan kita di hadapan orang lain, membayangkan penilaian mereka terhadap penampilan kita, dan (3) merasa sakit hati atau bangga karena perasaan diri.

3. Masyarakat (Society) adalah jejaring hubungan sosial yang diciptakan, dibangun, dan dikonstruksikan oleh tiap individu ditengah masyarakat, dan tiap individu tersebut terlibat dalam perilaku yang mereka pilih secara aktif dan sukarela, yang pada akhirnya mengantarkan manusia dalam proses pengambilan peran di tengah masyarakatnya. Oleh karena itu masyarakat terdiri dari individuindividu yang terbagi kedalam dua bagian masyarakat yang mempengaruhi pikiran dan diri.

Masyarakat yang pertama disebut Mead sebagai particular others yang berisikan individu yang bermakna bagi individu yang bersangkutan seperti anggota keluarga, teman dan rekan kerja, sedangkan masyarakat yang kedua adalah generalized others yang merujuk pada kelompok sosial dan budayanya secara keseluruhan. Generalized others menyediakan informasi tentang peranan, peraturan dan sikap yang digunakan bersama oleh komunitas, sedangkan particular others memberikan perasaan diterima dalam masyarakat dan penerimaan diri. Generalized others seringkali membantu mengatasi konflik yang terjadi dalam particular others. Dari pemaparan tentang latar belakang pemikiran besar tentang manusia yang mempengaruhi pemikirannya.

\section{METODE PENELITIAN}

Pendekatan penelitian yang digunakan dalam penelitian ini adalah paradigma konstruktivis dengan metode deskriptif. Metode deskriptif adalah suatu metode dalam meneliti status sekelompok manusia, suatu obyek, suatu set kondisi, suatu sistem pemikiran, ataupun suatu kelas peristiwa pada masa sekarang.

Tujuan dari penelitian deskriptif ini adalah untuk membuat deskipsi, gambaran 
atau lukisan secara sistematis, faktual dan akurat mengenai fakta-fakta, sifat-sifat serta hubungan antar fenomena yang diselidiki.

"Metodologi adalah proses, prinsip, dan prosedur yang kita gunakan untuk mendekati problem dan mencari jawaban" (Mulyana, 2008: 145). Menurut Sugiyono (2007: 1), metode penelitian kualitatif merupakan suatu penelitian yang digunakan untuk meneliti pada objek yang alamiah dimana peneliti adalah sebagai instrumen kunci, teknik pengumpulan data dilakukan secara gabungan, analisis data bersifat induktif, dan hasil penelitian kualitatif lebih menekankan makna daripada generalisasi.

Penelitian kualitatif bertujuan mempertahankan bentuk dan isi perilaku manusia dan menganalisis kualitaskualitasnya, alih-alih mengubahnya menjadi entitas-entitas kuantitatif (Mulyana, 2008: 150).

Metode yang digunakan peneliti dalam penelitian ini adalah dengan menggunakan metode penelitian deskriptif dengan analisis data kualitatif. Disebut sebagai metode deskriptif karena penelitian ini tidak menggunakan hipotesis dan variabel melainkan hanya menggambarkan dan menganalisis kejadian yang ada tanpa perlakuan khusus atas objek-objek yang diteliti.

Mengenai tipe deskriptif, Jalaludin Rakhmat dalam buku Metode Penelitian Komunikasi menjelaskan bahwa "Penelitian deskriptif hanyalah memaparkan situasi atau peristiwa. Penelitian ini tidak mencari atau menjelaskan hubungan, tidak menguji hipotesis atau membuat prediksi". (Rakhmat, 2008: 24)

Lebih lanjut Jalaludin Rakhmat menjelaskan "Ciri lain metode deskriptif ialah titik berat pada observasi dan suasana alamiah (naturalisasi setting). Peneliti bertindak sebagai pengamat. Ia hanya membuat kategori pelaku, mengamati gejala, dan mencatatnya dalam buku observasi”. (Rakhmat, 2008: 25)

\section{Teknik Pengumpulan Data}

Teknik pengumpulan data dalam penelitian kualitatif adalah dengan melakukan observasi, wawancara mendalam, dan studi dokumentasi.

1) Observasi

Observasi yang dilakukan dalam penelitian ini adalah pengamatan. Pengamatan dilakukan dengan cara participant observation, terhadap objek yang diteliti yaitu yang berkaitan dengan hambatan komunikasi terapeutik yang dilakukan Bidan kepada Ibu Hamil dalam upaya penurunan AKI di kabupaten Serang. Observasi yang peneliti lakukan yaitu penelitian berdasarkan kondisi di lapangan, peneliti terlibat dalam kegiatan komunikasi terapeutik tersebut lalu mengamati gejala-gejala yang ada di lapangan yang kemudian dilakukan analisis untuk mendapatkan kesimpulan dari penelitian yang dilakukan.

2) Wawancara

Wawancara yang dilakukan penulis dalam penelitian dimaksudkan untuk mengetahui pandangan, kejadian, kegiatan, pendapat, perasaan dari nara sumber (subjek matter expert). Wawancara yang dilakukan yaitu untuk mengetahui mengenai hambatan komunikasi terapeutik yang dilakukan Bidan kepada ibu hamil. Penggunaan teknik ini sangat penting bagi 
penelitian kualitatif, terutama untuk melengkapi data dan upaya memperoleh data yang akurat dan sumber data yang tepat.

3) Studi Dokumentasi

Menurut Burhan Bungin (2007: 121), metode dokumenter adalah metode yang digunakan untuk menelusuri data historis. Dokumentasi dalam penelitian ini diperlukan terutama untuk memperkaya landasan-landasan teoritis dan mempertajam analisis penelitian yang berkaitan dengan hambatan komunikasi terapeutik bidan kepada ibu hamil dalam upaya penurunan AKI di kabupaten Serang.

\section{Informan Penelitian}

Dalam penelitian ini, peneliti menggunakan teknik sampling purposive, yakni memilih informan sesuai dengan kebutuhan peneliti. Jadi, peneliti mengambil empat informan yaitu:

1. Bidan Koordinator, Rina

2. Bidan Desa, Neneng

3. Pasien, Sumiati, 45 tahun, memiliki 4 orang anak

4. Pasien, Isti, 28 tahun, memiliki 2 orang anak

\section{HASIL DAN PEMBAHASAN}

Berdasarkan hasil observasi dan wawancara yang dilakukan, ada beberapa temuan di lapangan berkaitan dengan topik penelitian peneliti, yakni hambatan komuikasi terapeutik bidan kepada ibu hamil dalam upaya penurunan AKI di kabupaten Serang.

Hasil penelitian yang dilakukan menunjukkan bahwa proses komunikasi terapeutik yang dilakukan bidan kepada ibu hamil pada hakikatnya adalah proses penyampaian lambang yang berarti oleh bidan kepada ibu hamil, baik dengan maksud agar mengerti maupun agar berubah perilakunya.

Terlihat bahwa dalam komunikasi terdapat tiga unsur penting, yaitu : komunikator, pesan, dan komunikan. Komunikator adalah sumber yang memiliki ide atau gagasan mengenai sesuatu yang akan disampaikan kepada komunikan. Pesan adalah gagasan yang berupa lambang-lambang yang berarti dan disampaikan oleh komunikator kepada komunikan, sedangkan komunikan adalah orang atau badan yang menerima pesan. Kegiatan komunikasi tidak akan berjalan secara efektif apabila tidak didukung dengan ketiga faktor tersebut yaitu komunikator, pesan, dan komunikan.

Dengan demikian, agar komunikasi berlangsung secara efektif maka kita harus memerhatikan faktor-faktor tersebut, yaitu komunikator, pesan, dan komunikan. Faktor lain yang penting dalam suatu proses komunikasi adalah umpan balik atau efek. Umpan balik memegang peranan penting dalam komunikasi sebab ia menentukan berlanjutnya komunikasi atau berhentinya komunikasi yang dilancarkan oleh komunikator . Dengan kata lain, umpan balik menentukan sukses atau tidaknya sebuah proses komunikasi dilangsungkan.

\section{Bidan sebagai Komunikator}

Kredibilitas merupakan salah satu faktor dari komunikator yang mempunyai peranan penting agar pesan yang dikomunikasikan dapat berjalan lancar dan dapat diterima atau dipahami komunikan. Menurut Jalaludin Rakhmat (2008:257), dalam bukunya psikologi komunikasi, kredibilitas adalah, 
"seperangkat lambang bermakna yang disampaikan oleh komunikator. Dalam penelitian peneliti, kredibilitas bidan tentu menjadi point penting yang menunjang keberhasilan proses komunikasi terapeutik.

2. Sosialisasi sebagai Pesan

Pesan merupakan seperangkat lambang bermakna yang disampaikan oleh komunikator (Effendy, 1998). Dalam menyampaikan pesan secara lisan, faktor pemilihan kata-kata merupakan hal yang sangat penting agar sasaran yang dituju mengerti dengan maksud yang disampaikan. Dalam penelitian ini, bidan menyampaikan sosialisasi kepada para pasien yang berkaitan dengan upaya penurunan AKI di kabupaten Serang.

3. Pasien Ibu Hamil sebagai Komunikan

Pasien yang menjadi komunikan dalam hal ini bisa siapa saja, tetapi untuk kasus AKI biasanya diberikan pesan secara spesifik kepada para ibu hamil.

Umpan balik dari komunikan bisa bersifat verbal dalam bentuk, seperti "ya" untuk tanda setuju atau "tidak" untuk tanda menolak, bisa juga bersifat non verbal dalam bentuk gerakan anggota kepala tanda tidak mau, mengerutkan kening tanda tidak mengerti, mencibirkan bibir tanda mengejek, dan lain-lain. (Effendy, 1994).

\section{Hambatan Komunikasi Terapeutik Bidan kepada Ibu Hamil dalam Upaya Penurunan Angka Kematian Ibu (AKI)}

Peneliti melakukan observasi partisipan untuk mengetahui lebih jelas tentang proses komunikasi terapeutik yang telah dilakukan kepada pasien. Hal ini ditujukan agar peneliti dapat memahami hambatan apa saja yang menyebabkan AKI ini masih tinggi, khususnya di kabupaten Serang. Melalui observasi partisipan, peneliti dapat mengamati langsung proses komunikasi terapeutik yang dilakukan, termasuk feedback yang diberikan oleh pasien. Maka, dari situlah, peneliti menemukan hambatan-hambatan komunikasi terapeutik bidan kepada ibu hamil, yang menyebabkan AKI nya pun masih tetap tinggi.

Selain itu, peneliti pun melakukan proses wawancara dengan beberapa informan, yaitu kepada Bidan sebagai komunikator, dan para pasien sebagai komunikan, yang dalam hal ini berperan sebagai komponen komunikasi terapeutik.

Bidan Koordinator, Rina, yang menangani beberapa kasus kesehatan di puskesmas Tunjung Teja ini, mengatakan bahwa:

"Betul, ada beberapa kasus kesehatan yang datanya itu tinggi sekali di puskesmas ini. Salah satunya, ya Angka Kematian Ibu (AKI), yang gak ada ujungnya. Hampir setiap tahun AKI ini menunjukkan jumlah yang tinggi. Kami sebagai tenaga medis di sini tentunya makin prihatin dengan kondisi ini. Padahal berbagai upaya telah kami lakukan, ada bidan desa, yang pastinya turun langsung ke desa-desa, penyuluhan yang rutin juga kami agendakan supaya para pasien semakin mengerti dengan kondisi AKI yang memprihatinkan ini. Malahan, saya sendiri aktif untuk berkomunikasi langsung dengan para ibu itu, jadi dibuatlah kaderisasi ibu-ibu, 
supaya saya mudah untuk menyampaikan pesan-pesan penting kepada mereka."

Pernyataan tersebut telah menunjukkan bahwa pihak dinas kesehatan di kabupaten Serang, khususnya dalam penelitian ini adalah puskesmas Tunjung Teja, telah melakukan berbagai upaya guna menunjang terealisasinya penurunan AKI di kabupaten Serang.

Peneliti pun mengamati langsung bagaimana Koordinator Bidan tersebut melakukan proses komunikasi terapeutik kepada para pasiennya. Beliau sangat gesit dan informatif dalam menyampaikan pesan-pesan penting yang semestinya diketahui oleh para pasien. Proses komunikasi yang tampak pun berjalan lancar.

Begitupun halnya ketika peneliti melakukan wawancara kepada Neneng, sebagai bidan desa. Mereka memberikan penuturan yang serupa, bahwa mereka merasa telah melakukan berbagai upaya kepada para pasien, khususnya di sini, adalah ibu hamil, agar semakin mengerti dan berupaya mendukung program pemerintah kabupaten Serang untuk menurunkan Angka Kematian Ibu (AKI).

Peneliti pun melakukan wawancara dengan beberapa pasien untuk mendapatkan data yang akurat tentang hambatan komunikasi terapeutik ini. Adapun hasil penelitian yang ditemukan peneliti tentang hambatan komunikasi terapeutik ini, digolongkan dalam beberapa hal di bawah ini:

1. Hambatan Semantik (Bahasa).

Seorang pasien bernama Sumiati, berusia 45 tahun, telah memiliki 4 orang anak, menyampaikan penuturannya kepada peneliti ketika ditanyakan tentang proses komunikasi terapeutik yang dilakukan bidan :
"Iya bu, saya suka dikasih tau soal Angka Kematian Ibu (AKI). Ngeri yah, tapi gimana ya, kadang saya juga ya gitu bu, ngerti gak ngerti gitu, hehe... Jadi saya kalo dibilangin tuh, iya iya aja gitu bu. Terus kalo ngobrol sama tetangga, saudara juga, kita ngobrolin yang umum aja gitu bu, gak pernah ngobrolin ya soal apa itu, Angka Kematian Ibu ya. Saya gak ngerti juga bu dari bahasa-bahasanya kadang istilahnya gak ngeuh gitu bu, hehe.."

Pasien selanjutnya, bernama Isti, berusia 28 tahun, sudah memiliki 2 orang anak, juga memiliki pendapat yang hampir sama dengan informan sebelumnya:

"Iya suka ada penyuluhan di puskesmas Tunjung Teja ini, saya suka disuruh ikut sama bidan desanya, malahan suka ditelponin sama bidan koordinatornya, bu Rina itu baik banget bu, perhatian gitu sama warga di desa sini tuh. Terus suka ngasih informasi macem-macem bu, gak cuma soal apa tuh, Angka Kematian Ibu yah, tapi soal gizi buruk juga buat anak sama ibu hamilnya. Tapi ya gimana bu, saya kadang gak ngerti juga, terus kalo udah di rumah ya jadi lupa lagi gitu bu, hehe... Apalagi kalo udah kerja, kan saya suka ikut ke sawah gitu bu, seharian, ya pulang-pulang pas udah sore aja, makan ya seingetnya aja gitu bu, anak juga kalo saya ke sawah, ga makan juga kayaknya, hehe...Tapi gimana lagi bu, kan hidup juga perlu uang ya bu.."

Hasil wawancara yang dilakukan peneliti dari informan ini menunjukkan adanya hambatan yang pertama, dalam proses komunikasi terapeutik bidan kepada pasiennya, yakni hambatan semantik atau bahasa. 
Berdasarkan tinjauan pustaka yang telah dijelaskan di atas bahwa hambatan semantik adalah hambatan yang berasal dari keterbatasan simbol-simbol itu sendiri. Ada beberapa karakteristik dari bahasa yang menyebabkan proses decording dalam bahasa semakin sulit antara lain :

a.Bahasa itu statis sedangkan realitasnya dinamis,

b.Bahasa itu terbatas sedangkan realitasnya tidak terbatas,

c.Bahasa itu bersifat abstrak.

Hal ini terbukti dengan hasil wawancara yang dilakukan kepada para pasien yang berperan sebagai komunikan dalam proses komunikasi terapeutik ini. Jadi, hambatan yang pertama adalah bahasa, bahwa ketika para bidan atau tenaga medis lainnya telah menyampaikan berbagai macam informasi pesan yang sangat penting, dalam berbagai macam bentuk, termasuk dengan menggunakan media, seperti spanduk, brosur, pamflet, dan lain-lain, ternyata bahasa yang diterima oleh para pasien dianggap sebagai bahasa yang sulit untuk dimengerti. Meskipun, bidan koordinator, telah melakukan pendekatan psikologis, sampai membentuk kaderisasi ibu-ibu untuk memudahkan koordinasi dalam penyampaian informasi.

Ketika peneliti melanjutkan wawancara kepada para pasien tentang informasi pesan yang disampaikan melalui media, Sumiati menjawab sebagai berikut: "Aduh, saya ga tau, gak pernah merhatiin juga, hehe... gak pernah ngeuh gitu bu kalo ada spanduk, ada poster, sama yang lain. Iya kalo ada juga banyak dipasang di sini, tapi saya nya ga baca aja mungkin ya, hehe.."

Berdasarkan wawancara tersebut, jadi ditemukanlah hambatan yang pertama dalam komunikasi terapeutik bidan kepada pasiennya ini adalah hambatan semantik (bahasa).

2. Hambatan Budaya

Berdasarkan hasil penelitian yang dilakukan, peneliti menemukan hambatan yang kedua dalam proses komunikasi terapeutik ini, yaitu hambatan budaya.

Hambatan budaya ini menjadi hal yang sangat penting. Satu pantangan bagi sang komunikator untuk beranggapan, bahwa komunikan tumbuh dengan filosofi, gaya hidup, adat istiadat yang sama. Maka kita tidak boleh "menyamaratakan" penggunaan teknik berkomunikasi kepada setiap komunikan.

Hal ini bisa saja terjadi karena budaya yang berbeda yang dimiliki oleh sang komunikan. Dalam penelitian peneliti, komunikan di sini adalah para pasien atau ibu hamil tersebut.

Peneliti melihat adanya hambatan budaya dalam proses komunikasi terapeutik ini karena pernyataan informan, Isti, yang memberikan penuturan sebagai berikut:

"Kalau soal informasi yang umum tadi itu ya udah dikasih tau sama bidan-bidannya bu, termasuk bidan koordinator, bu Rina yang paling gesit ngasih kabar gitu. Tapi saya kalo ga ngerti ya gimana juga bu, apalagi saya sekolah kan sampai SD aja bu, jadi ya ga begitu paham juga. Kalo saya sih ngertinya, ya ngikutin kata orangtua di desa-desa aja, kan kalo udah takdirnya meninggal, ya gimana ya bu, kan katanya udah ada Allah yang ngatur soal hidup dan mati ya. Kalo saya ngobrol sama ibu-ibu yang lain juga ya gitu sama bu, iya udah takdirnya aja sih. Jadi, kadang ga ngerti juga kalo udah dikasih tau soal Angka Kematian Ibu yang tinggi, ya gimana lagi." 
Berdasarkan pernyataan di atas, peneliti menemukan adanya hambatan budaya yang menjadi hambatan juga dalam proses komunikasi terapeutik yang dilakukan bidan kepada pasiennya, khususnya dalam upaya penurunan Angka Kematian Ibu (AKI). Peneliti melihat adanya budaya, tradisi, dan kepercayaan yang mereka pegang kuat jikalau itu berasal dari orangtua, leluhur, atau nenek moyangnya. Mereka lebih mempercayai itu dibandingkan dengan fakta yang ditunjukkan oleh para tenaga medis yang ada, seperti bidan, perawat, dokter, dan lain-lain.

Budaya memegang peranan
penting dalam keberhasilan proses komunikasi terapeutik. Apalagi jika telah berhubungan dengan kepercayaan yang menyebar secara turun temurun, adat istiadat dan budaya lah yang akan berhasil dalam proses penyampaian pesan.

3. Hambatan Psikologis

Selain kedua hambatan di atas, peneliti juga menemukan adanya hambatan psikologis yang menjadi gangguan / noise dalam proses komunikasi terapeutik yang dilakukan bidan kepada pasiennya.

Hambatan Pribadi (Psikologis) adalah gangguan komunikasi yang timbul dari emisi, nilai, dan kebiasaan menyimak yang tidak baik. Hambatan pribadi seringkali mencakup jarak psikologi di antaranya orang-orang yang serupa dengan jarak fisik sesungguhnya. (Arni Muhammad: 2009).

Berdasarkan definisi di atas, hambatan psikologis juga terjadi dalam proses komunikasi terapeutik ini. Peneliti melihat adanya hambatan psikologis, karena ada emisi, nilai, dan kebiasaan menyimak yang tidak baik, yang ada dalam diri para pasien sebagai komunikan. Hal ini tercermin dalam penuturan informan, Sumiati, yang bercerita tentang dirinya:

"Hehe..iya bu jadi kalo pas bidan lagi menyampaikan informasi tuh yah, ya soal AKI ini, gizi buruk, atau soal kasus yang lain, pas lagi itu aja saya iya iya gitu, padahal kadang saya ga menyimak juga bu. Kan kalo kurang tidur misalnya bu, saya jadi ngantuk bu, belum lagi kalo banyak pikiran ya bu, aduh apalagi kalo gak punya uang, haha.. Jadi, saya kadang ngedengerin bener tapi jadi lupa lagi, tapi kadang gak merhatiin juga gitu bu. Abis gimana lagi ya bu, saya juga bingung, hehe.."

Peneliti menemukan adanya hambatan psikologis yang dirasakan para pasien, sebagai komunikan dalam proses komunikasi terapeutik yang dilakukan bidan kepada pasiennya. Hambatan psikologis ini tampak sepele, tapi bisa menjadi gangguan yang utama, apalagi jika sesuai dengan yang disampaikan oleh penuturan informan, karena ini sangat erat dengan diri seseorang. Mulai dari tingkat kognisi, pemahaman, dan perilaku individu, dalam hal ini adalah para pasien, tentu akan memicu timbulnya hambatan psikologis.

\section{Analisis Teori Interaksi Simbolik}

George Herbert Mead menjelaskan konsep dasar dari interaksi simbolik, yang dapat disimpukan bahwa terdapat tiga tema konsep interaksi simbolik, yaitu :

1. Pentingnya makna bagi perilaku manusia, dalam penelitian peneliti, pentingnya makna penurunan AKI yang harus disepakati oleh bidan dan pasien.

2. Pentingnya konsep mengenai diri, dalam penelitian peneliti, pentingnya konsep diri setiap pasien dalam 
memahami pesan yang disampaikan oleh bidan.

3. Hubungan antara individu dengan masyarakat, dalam penelitian ini, terlihat adanya hubungan antara pasien dengan lingkungan masyarakatnya, yang akan mempengaruhi keberhasilan proses komunikasi terapeutik yang dilakukan bidan dalam upaya penurunan AKI di kabupaten Serang.

Aktivitas individu dalam

menggunakan simbol atau bahasa dilakukannya melalui interaksi dengan masyarakat. Hasil aktivitas individu ini akan berpengaruh pada masyarakat tempat individu tersebut berinteraksi. Hubungan antara masyarakat dan individu yang berinterkasi menggunakan simbol-simbol yang sama, akan mereka maknai sesuai dengan interaksi mereka tersebut. Interaksi menggunakan simbol yang sama dalam suatu masyarakat ini dapat membentuk konstruksi realitas sosial bagi individu yang terlibat di dalamnya.

Simbolisme suatu makna bukan hanya bahasa, simbolisme adalah semua aspek tindakan manusia. Hal ini bukanlah ide baru, tetapi bahasa telah sangat diistimewakan dalam karya-karya para ahli interaksi simbolik. Interaksi simbolik memungkinkan manusia untuk memahami realitas dan berinteraksi dengan manusia lain dalam suatu proses komunikasi, dalam arti pesan yang dimaknai dan ditransformasikan pada pihak lain pada akhirnya dapat mempengaruhi pihak kedua dalam suatu proses komunikasi yang timbal balik. Hal ini relevan dengan penelitian peneliti, para informan, dalam hal ini adalah para pasien yang mengalami transformasi pesan, di mana pesan yang dimaknai dan ditransformasikan pada para anggotanya dapat mempengaruhi proses komunikasi yang terjadi di antara mereka.
Meskipun sedikit demi sedikit, informasi yang disampaikan oleh bidan lalu diserap oleh para pasien, hal ini dapat membantu proses keberhasilan komunikasi terapeutik yang dilakukan bidan. Adanya hambatan bahasa, hambatan budaya, dan hambatan psikologis yang terjadi selama proses komunikasi terapeutik ini, tentu memungkinkan para pasien untuk memahami realitas dan berinteraksi dengan bidan dalam proses transformasi pesan, seperti yang diungkapkan George Herbert Mead melalui teori interaksi simbolik ini.

\section{PENUTUP}

\section{Kesimpulan}

Berdasarkan hasil penelitian dan pembahasan yang telah dilakukan, peneliti menyimpulkan adanya hambata komunikasi terapeutik bidan kepada ibu hamil dalam upaya penurunan Angka Kematian Ibu (AKI) di kabupaten Serang, sebagai berikut:

1. Hambatan Semantik (Bahasa)

Hambatan yang pertama adalah bahasa, bahwa ketika para bidan atau tenaga medis lainnya telah menyampaikan berbagai macam informasi pesan yang sangat penting, dalam berbagai macam bentuk, termasuk dengan menggunakan media, seperti spanduk, brosur, pamflet, dan lainlain, ternyata bahasa yang diterima oleh para pasien dianggap sebagai bahasa yang sulit untuk dimengerti. Meskipun, bidan koordinator, telah melakukan pendekatan psikologis, sampai membentuk kaderisasi ibuibu untuk memudahkan koordinasi dalam penyampaian informasi.

2. Hambatan Budaya 
Peneliti melihat adanya budaya, tradisi, dan kepercayaan yang mereka pegang kuat jikalau itu berasal dari orangtua, leluhur, atau nenek moyangnya. Mereka lebih mempercayai itu dibandingkan dengan fakta yang ditunjukkan oleh para tenaga medis yang ada, seperti bidan, perawat, dokter, dan lainlain.

3. Hambatan Psikologis

Hambatan psikologis ini tampak sepele, tapi bisa menjadi gangguan yang utama, apalagi jika sesuai dengan yang disampaikan oleh penuturan informan, karena ini sangat erat dengan diri seseorang. Mulai dari tingkat kognisi, pemahaman, dan perilaku individu, dalam hal ini adalah para pasien, tentu akan memicu timbulnya hambatan psikologis.

\section{Saran}

Adapun saran yang diberikan peneliti berkaitan dengan penelitian yang telah dilakukan tentang hambatan komunikasi terapeutik bidan kepada ibu hamil dalam upaya penurunan Angka Kematian Ibu (AKI) di kabupaten Serang, sebagai berikut:

Dalam upaya mencapai keberhasilan penurunan Angka Kematian Ibu (AKI), sebaiknya pihak tenaga medis, dalam hal ini bidan maupun tenaga medis lainnya, tetap semangat dan saling bekerjasama untuk memerhatikan setiap hambatan komunikasi yang menjadi gangguan dalam proses komunikasi terapeutik tersebut. Hal ini mengingat, bukanlah hal yang mudah untuk mengatasi setiap hambatan komunikasi yang ada, tetapi sebagai komunikator, dituntut untuk selalu aktif agar tujuan pesannya tersebut dapat tercapai.

Setelah ditemukannya hambatan dalam proses komunikasi terapeutik ini, alangkah baiknya jika dilakukan evaluasi dalam menyusun rencana atau program baru yang lebih variatif agar pasien semakin paham dengan konsep pentingnya penurunan AKI tersebut. 


\section{REFERENSI}

Arni Muhammad. 2009. Komunikasi

Organisasi. Jakarta: Bumi Aksara

Bungin, Burhan. 2007. Penelitian

Kualitatif. Jakarta: Kencana Prenada

Media Group

Damaiyanti, Mukhripah. 2010. Komunikasi Terapeutik Dalam Praktik Keperawatan. Bandung: Rifika Aditama.Cetakan Kedua.

Depkes, RI Nomor: 63/ KES / 23 / 2011.

Tentang Pedoman umum Asuhan Kesehatan.

Effendy, Onong Uchjana. 1998. Ilmu Komunikasi, Teori, dan Praktek. Bandung: Remaja Rosdakarya

Hakim, M. Lukman, Sinduwiatmo, Kukuh. Jurnal Elektronik : Pengaruh Komunikasi Terapeutik Bidan Terhadap Kepuasan Pasien Bersalin Di Rumah Sakit Bhayangkara Pusdik
Brimob Watukosek Gempol Pasuruan. Jurnal Online KANAL, Vol. 2, No. 1, September 2013.

Machfoedz, Mahmud. 2009. Komunikasi Terapeutik, Yogyakarta: Ganbika

Mulyana, Deddy. 2008. Metodologi Penelitian Komunikasi. Bandung: Remaja Rosda Karya.

Rakhmat, Jalaludin. 2008. Psikologi Komunikasi. Bandung : Remaja Rosdakarya.

Rakhmat, Jalaludin. 2009. Metode Penelitian Komunikasi. Bandung : Remaja Rosdakarya.

Sugiyono. 2007. Metode Penelitian Kuantitatif, Kuantitatif dan $R \& D$. Bandung: Alfabeta.

West, Richard. Lynn H.Turner. 2007. "Pengantar Teori Komunikasi". Jakarta: Salemba Humanika. 
